\title{
Effects of woody vegetation patches on species composition in Stipa tenacissima steppes
}

\author{
J. Tormo $^{\mathrm{a}, *}$, B. Amat ${ }^{\mathrm{b}}$, J. Cortina ${ }^{\mathrm{b}}$ \\ a Department of Agrarian and Environmental Sciences. Technological College, Agri-food and Environment. Environmental Sciences Institute (IUCA), University of Zaragoza, Spain \\ ${ }^{\mathrm{b}}$ University of Alicante, Department of Ecology and IMEM, Ap. 99, 03080, Alicante, Spain
}

\section{A R T I C L E I N F O}

\section{Keywords}

Agricultural abandonment

Shrub encroachment

Facilitation

Drylands

Recruitment

Community assembly

Climate change

Desertification

\begin{abstract}
A B S T R A C T
Stipa tenacissima steppes cover $70,000 \mathrm{~km}^{2}$ in the Mediterranean basin. In these habitats, resprouting shrubs form woody patches that were removed in the past to promote fiber and forage production. Patches are recovering after decades of abandonment. Patches enhance plant richness and affect ecosystem functioning. Yet, they have been commonly considered as a single entity, paying scarce attention to patch heterogeneity, patch dynamics and their impact on community composition. We describe the physical and biotic structure of 450 patches in 15 catchments along a climate gradient in southeastern Spain, and analyze the drivers of overstory and understory composition and recruitment of patch-forming species. Patches were formed by one to six species (Quercus coccifera, Juniperus oxycedrus, Rhamnus lycioides, Ephedra fragilis, Pistacia lentiscus and Osyris lanceolata). Climate determined the species composition in each patch, their physical characteristics and the recruitment of patch-forming species. Species cover and richness depended on the dominant species. Our results suggest that patches dominated by Quercus coccifera and Juniperus oxycedrus may decline and patches dominated by Rhamnus lycioides and Ephedra fragilis may expand as climate warms. They also provide new insights on the interactions in patch communities very relevant for the conservation and management of $S$. tenacissima steppes.
\end{abstract}

\section{Introduction}

Drylands cover around $45 \%$ of the world's land area (Prăvălie, 2016). Climate models suggest that dryland cover will increase by $23 \%$ by the end of this century (Huang et al., 2016). In drylands, vegetation is frequently patchy, and this structure is closely linked to ecosystem function (Berdugo et al., 2020). Vegetation patches modulate the flow of water, nutrients and sediments, acting as resource sinks (Ludwig and Tongway, 1995; Aguiar and Sala, 1999; Merino-Martín et al., 2015). They also affect community composition and species richness (Ludwig et al., 2004; Zhang et al., 2016).

Steppes dominated by the tussock grass Stipa tenacissima L. cover $70,000 \mathrm{~km}^{2}$ in the western Mediterranean basin. They frequently form mosaics of woody vegetation patches immersed in a matrix of $S$. tenacissima tussocks, small sub-shrubs and bare soil. In $S$. tenacissima steppes, patches of woody species act as keystone components of the community (sensu Hurlbert, 1997), their cover is often low, but they affect ecosystem functioning, vascular plant richness, and plant and soil macroinvertebrate communities (Maestre and Cortina, 2004, 2005; Doblas-Miranda et al., 2009; Rolo et al., 2016). Woody patches in S. tenacissima steppes modify climate and soil properties favoring the establishment of shade tolerant species at their understory (Maestre and Cortina, 2005). These species benefit from the decrease in evaporative demand and temperature range, and the increase in soil fertility to the point that they may withstand the reduction in soil water availability (Amat et al., 2015).

In $S$. tenacissima steppes, woody vegetation was removed in the past to reduce competition and promote forage and fiber production (Servicio del Esparto, 1953; Fernández-Palazón, 1974, Gasque and García-Fayos, 2004). In the early stages of succession, patches of woody species are usually associated with the margins of abandoned agricultural terraces and rock outcrops unsuitable for agriculture (Cortina et al., 2009; Rolo et al., 2016). Steppe colonization by patch-forming species may be initiated in these patches, and progress at rates that depend on climatic conditions -particularly water availability, topography, soil fertility, and species dispersal and establishment ability (Rolo et al., 2016; Tormo et al., 2012, Castillo-Escrivà et al., 2019). Furthermore, establishment may be driven by the dynamic nature of positive and negative plant-plant and plant-animal interactions (Maestre and Cortina, 2004, Soliveres et al., 2015; Amat et al., 2015, Castillo-Escrivà et al., 2019). However, studies on woody patch dynamics have paid scarce attention to their multi-specific nature

\footnotetext{
* Corresponding author.

E-mail address: jtormo@unizar.es (J. Tormo)
} 
by considering them as homogeneous entities or focusing solely on patch-forming species. No study has described so far the composition of patch-forming species and the drivers controlling patch composition.

Patch capacity to modify the environment depends on their composition and size. For example, contrasting rooting habits, water and nutrient demand, litter accumulation, and the amount and quality of radiation in the understory in different patch-forming species generate different microhabitats and colonization opportunities (Aguiar et al., 1992; Archer et al., 2002; Blank and Carmel, 2012; Arroyo et al., 2015). Furthermore, as patches increase in size, they provide further opportunities for colonization because of the intensification of the environmental effects, the time elapsed since the establishment of the first patch-forming species, and the increase in habitat heterogeneity. Heterogeneity in environmental conditions within the patches has been well characterized in drylands - including $S$. tenacissima steppes, as well as its effects on community composition and plant functional traits (Hochstrasser and Peters, 2004, Holmgren et al., 2010; Pescador et al., 2014; Amat et al., 2015; Soliveres et al., 2015). Yet, our knowledge on the heterogeneity of woody patches in $S$. tenacissima steppes, its drivers and its role in community assemblage is still scarce.

To better understand patch features and the effect of woody patches on community composition, we studied the cover of vascular plants in 450 woody patches distributed in 15 small catchments dominated by S. tenacissima steppes along a climatic gradient in southeastern Spain, and generated explanatory models of overstory and understory composition and the recruitment of patch-forming species based on patch and catchment characteristics.

\section{Material and methods}

We selected 15 catchments along a $60 \mathrm{~km}$-transect in a semiarid area in Alicante, southeastern Spain (Fig. 1, Table 1). Catchment slopes are covered with $S$. tenacissima steppes, whereas catchment bottoms are frequently occupied by abandoned rainfed agricultural ter- races. We intentionally excluded catchments with a significant presence of Pinus halepensis Mill., because this species has often been planted, and planting techniques alter soils and vegetation. In each catchment, we sampled variables describing the whole catchments, the slopes and the agricultural terraces, as well as the woody patches (Table S1). Only perennial species were taken into account for the analyses, as they dominate plant cover in $S$. tenacissima steppes in southeastern Spain and show less inter and intra-annual variability in abundance than annual plants.

\subsection{Catchment characterization}

Mean annual precipitation and temperature data were obtained from Atlas Climático Digital de la Península Ibérica (Ninyerola et al., 2005). Total surface area of each catchment and the number of woody patches in the slopes were estimated using aerial photographs and field surveys (Rolo et al., 2016). We identified as patch any cluster of woody vegetation $>1 \mathrm{~m}$ diameter. Finally, we measured soil depth in 30 randomly selected points across the whole catchment, excluding agricultural terraces. We used the distance from soil surface to bedrock or consolidated rock as indicator of soil availability. We hammered a $1 \mathrm{~cm}$ diameter iron rod into the soil until no further advance was perceptible. Based on this measure, we calculated an indicator of soil availability as the proportion of points where soil depth was lower than $30 \mathrm{~cm}$.

Because of the internal variability of the catchments, we stratified vegetation sampling within each catchment. Using aerial photographs and on-site surveys, we divided the slopes of each catchment into 1-3 different units that were relatively homogeneous in terms of exposure, topography and plant cover. A total of 27 units were selected across the 15 catchments. In each unit, we established 2 to $415 \times 21 \mathrm{~m}$-plots (49 plots in total; the number of plots per unit depending on unit size) (Fig. S1). In each plot, we quantified plant cover, and the cover of
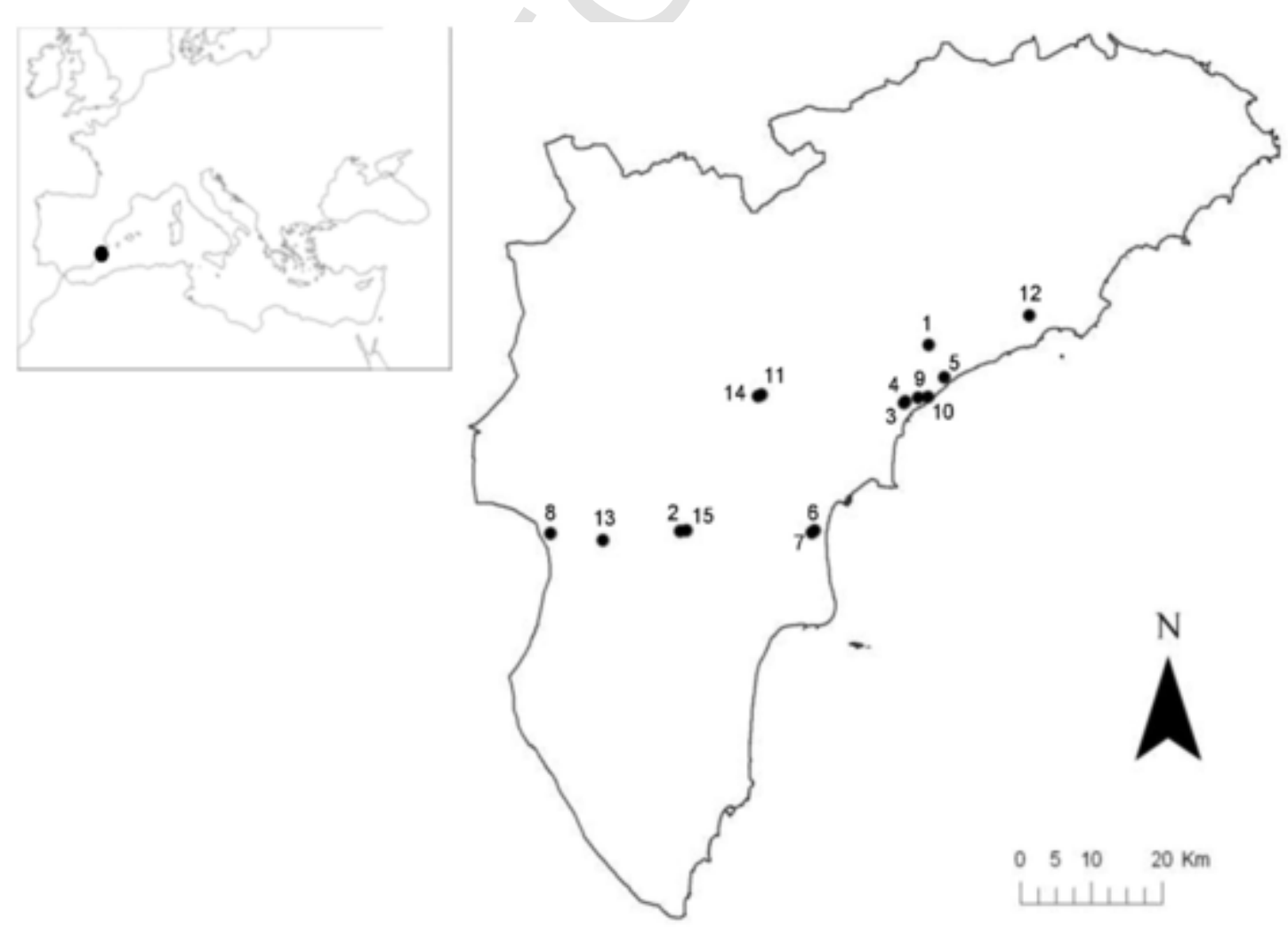

Fig. 1. Distribution of the 15 catchments studied in the province of Alicante, southeastern Spain. Catchment codes correspond to those shown in Table 1. 
Table 1

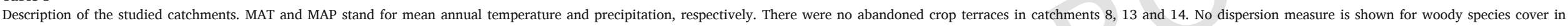
abandoned crop terraces because we used data from a single transect along each catchment.

\begin{tabular}{|c|c|c|c|c|c|c|c|c|c|c|c|c|c|c|}
\hline Code & $\begin{array}{l}\text { Catchment } \\
\text { name }\end{array}$ & $\begin{array}{l}\text { MAT } \\
\left({ }^{\circ} \mathrm{C}\right)\end{array}$ & $\begin{array}{l}\text { MAP } \\
(\mathrm{mm})\end{array}$ & $\begin{array}{l}\text { Catchment } \\
\text { surface area }\left(\mathrm{m}^{2}\right)\end{array}$ & $\begin{array}{l}\text { Abandoned crop } \\
\text { terraces surface area } \\
\left(\mathrm{m}^{2}\right)\end{array}$ & $\begin{array}{l}\text { No. } \\
\text { study } \\
\text { plots }\end{array}$ & $\begin{array}{l}\text { Total No. } \\
\text { patches }\end{array}$ & $\begin{array}{l}\text { Recruitment density } \\
\text { (recruits/ha) } \\
\text { mean } \pm \text { SE }\end{array}$ & Cover of $\mathrm{p}$ & orming spec & abandoned c & erraces (\%) & & \\
\hline & & & & & & & & & $\begin{array}{l}\text { Rhamnus } \\
\text { lycioides }\end{array}$ & $\begin{array}{l}\text { Juniperus } \\
\text { oxycedrus }\end{array}$ & $\begin{array}{l}\text { Osyris } \\
\text { lanceolata }\end{array}$ & $\begin{array}{l}\text { Quercus } \\
\text { coccifera }\end{array}$ & $\begin{array}{l}\text { Pistacia } \\
\text { lentiscus }\end{array}$ & $\begin{array}{l}\text { Ephedra } \\
\text { fragilis }\end{array}$ \\
\hline 1 & Aigües & 16 & 417 & 26,484 & 9130 & 4 & 69 & $198 \pm 123$ & 3.8 & 2.0 & 1.1 & 0.7 & 0.0 & 0.0 \\
\hline 2 & Aspe3 & 18 & 282 & 29,522 & 2166 & 4 & 365 & $183 \pm 120$ & 19.3 & 0.0 & 0.0 & 0.0 & 0.0 & 2.1 \\
\hline 3 & Ballestera1 & 18 & 343 & 23,624 & 2841 & 4 & 152 & $198 \pm 83$ & 7.4 & 0.0 & 0.0 & 0.0 & 1.9 & 0.0 \\
\hline 4 & Ballestera2 & 18 & 343 & 27,688 & 3641 & 3 & 156 & $116 \pm 103$ & 34.1 & 0.0 & 0.0 & 0.0 & 19.3 & 0.0 \\
\hline 6 & Colmenar2 & 18 & 300 & 13,851 & 170 & 4 & 212 & $508 \pm 484$ & 29.7 & 0.0 & 0.0 & 0.0 & 0.0 & 0.0 \\
\hline 7 & Colmenar3 & 18 & 300 & 41,128 & 1619 & 2 & 207 & $143 \pm 67$ & 20.5 & 0.0 & 0.0 & 0.0 & 8.0 & 0.0 \\
\hline 8 & Orihuela & 16 & 361 & 97,317 & 0 & 3 & 306 & $85 \pm 73$ & - & - & - & - & - & - \\
\hline 9 & Porxa & 18 & 368 & 51,235 & 9976 & 3 & 264 & $413 \pm 366$ & 18.6 & 0.4 & 3.0 & 2.8 & 8.9 & 0.0 \\
\hline 10 & Torreón & 18 & 343 & 30,647 & 3049 & 4 & 139 & $497 \pm 275$ & 8.6 & 0.0 & 6.5 & 2.4 & 9.0 & 0.8 \\
\hline 11 & Ventós1 & 15 & 293 & 34,194 & 1390 & 3 & 143 & $42 \pm 18$ & 1.0 & 0.0 & 0.0 & 0.0 & 0.0 & 0.0 \\
\hline 12 & Vila & 17 & 525 & 50,626 & 11,596 & 4 & 211 & $286 \pm 266$ & 6.5 & 0.2 & 8.1 & 0.0 & 8.9 & 0.4 \\
\hline 13 & Crevillente & 16 & 382 & 25,183 & 0 & 3 & 228 & $402 \pm 247$ & - & - & - & - & - & - \\
\hline 14 & Ventós3 & 16 & 288 & 28,209 & 0 & 3 & 107 & $11 \pm 18$ & - & - & - & - & - & - \\
\hline 15 & Aspe5 & 18 & 306 & 11,998 & 968 & 2 & 163 & $270 \pm 112$ & 14.1 & 0.0 & 0.0 & 0.0 & 0.0 & 1.4 \\
\hline
\end{tabular}


loose rocks and rock outcrops by visual estimation in 14 consecutive $1.5 \times 1.5 \mathrm{~m}$-quadrats along a downslope belt transect. Total plant cover was estimated as the sum of the plant cover of all species present in each quadrat (thus, values above $100 \%$ indicate canopy overlapping). Species richness was derived from these data. In each plot, we also recorded all individuals of patch-forming species whose canopy projected area was less than $1 \mathrm{~m}^{2}$

\subsection{Vegetation in abandoned crop terraces}

We estimated the surface area covered by agricultural terraces using aerial photographs and in situ surveys. In each catchment, we selected one third of the terraces randomly, and set linear transects perpendicular to the stone walls. We used the point-intercept method at 1-m intervals to record the identity of all vascular plants in the sampled terraces and calculate their frequency.

\subsection{Patch characterization}

We located and geo-referenced all woody patches in each catchment by using aerial photographs and field surveys (Rolo et al., 2016). Then, we randomly selected 30 patches per catchment for patch characterization. As patches were chosen at random, we considered that patch attributes represented the actual status of woody vegetation patches in each catchment. In each patch, we differentiated two groups of vascular plants: patch-forming and accompanying species. Patch-forming species are large resprouting shrubs which are main components of woody patches and barely appear in isolation when adults. Accompanying species are small shrubs, herbs and grasses which are present in the understory of the patches but may also grow independently of them.

We recorded the aspect, slope and specific location of each woody patch. We measured the maximum canopy height, the maximum canopy diameter and the orthogonal diameter for the whole patch and for each patch-forming species within the patch (Table S1). Litter depth and soil depth were measured in 6-10 randomly distributed points underneath the patches, the number of points depended on canopy projected area. Soil depth was measured as described above.

We also recorded the identity and cover of all accompanying species underneath the canopy and in the periphery of each patch. For this, we set a belt transect along each patch and parallel to the slope. Transects extended $1 \mathrm{~m}$ upslope and $1 \mathrm{~m}$ downslope from the patch, and their length was thus dependent on patch size. We visually estimated the cover of each accompanying species in consecutive $50 \times 50$ $\mathrm{cm}$-quadrats along the transects.

\subsection{Statistical analysis}

We used linear mixed models (LMM) to integrate the spatial structure of the sampling design, with catchment as a random factor, and factor Unit nested within catchments. We used generalized linear mixed models (GLMM) with Poisson error distribution when data did not fit model requirements and could not be transformed. Similarly, patch was considered a random factor when analyzing differences in plant cover in different parts of the patch understory, to account for their lack of independence. The significance of the differences between attributes of patch-forming species were tested by means of Fisher LSD (Recruitment density) and Tukey HSD test (other variables), as the effect of the former variable could not be separated by means of Tukey HSD test.

We used Non-metric Multidimensional Scaling (NMDS) to understand how environmental variables (mean annual precipitation and air temperature, aspect, slope, stoniness, plant cover, and the cover of loose rocks and rock outcrops) determined the cover of patch-forming species in the patches. First we built an ordination of the patches based on the cover of patch-forming species. Then, we fitted the environmental variables and the cover of each patch-forming species onto the ordination. NMDS has been recommended over other ordination techniques for community analysis because it does not ignore community structure that is unrelated to environmental variables, and it does not assume multivariate normality (McCune and Grace, 2002). We used Bray-Curtis distance measures with random starting configurations for NMDS. We found no correlation among predictor variables. We used a similar strategy to understand how environmental variables and patch-forming species determined the cover of accompanying species in the patches. First, we built an ordination of the patches based on the cover of accompanying species, and then we fitted environmental variables and the cover of patch-forming species onto this ordination. Later, we used regression analysis to determine the level of covariance between the cover of accompanying species, environmental variables and the cover of patch-forming species. Finally, using the axes of the accompanying species ordination, we tested the effect of environmental variables and cover of patch-forming species on understory composition by means of a PERMANOVA. This allowed us to take the spatial structure of the data into account by analyzing the interaction between environmental variables, patch-forming species and catchment.

All analyses were performed using R 3.6.1 statistics software ( $R$ Development core team, 2018), and packages lme4 (Bates et al., 2015) and Vegan (Oksanen et al., 2019).

\section{Results}

\subsection{Patch-forming species in slopes and abandoned terraces}

The number of woody patches in the slopes of the studied catchments ranged from 69 to 365, which corresponds to a range of densities of 31-155 patches/ha (Table 1). We identified six patch-forming species: Pistacia lentiscus L., Quercus coccifera L., Rhamnus lycioides L., Juniperus oxycedrus L., Ephedra fragilis Desf. and Osyris lanceolata Hochst. \& Steud. Patches dominated by $R$. lycioides (i.e, patches where canopy projection area of $R$. lycioides was bigger than the projected area of any other patch-forming species) were the most abundant, followed by patches dominated by $Q$. coccifera and P. lentiscus (Fig. 2).

The area covered by abandoned crop terraces, ranged from 0.02 to 11.60 ha, or $1 \%-35 \%$ of the whole catchments. The cover of patch-forming species in abandoned crop terraces was highly variable. Rhamnus lycioides was present in the terraces of all catchments, being the only species present in catchments 6 and 11. The mean cover of $R$. lycioides was $15 \pm 3 \%$, which more than doubled the cover of other patch-forming species. The cover of $Q$. coccifera, $E$. fragilis and $J$. oxycedrus was low in all terraces. Thus, the pattern of dominance in abandoned terraces was similar to slopes for all patch-forming species but $Q$. coccifera. Yet, the number of woody patches in slopes did not correlate with the cover of patch-forming species in abandoned crop terraces $\left(\mathrm{R}^{2}=0.035\right.$, $\mathrm{p}=0.264$ ).

The number of species under the patches and at their periphery was positively related to patch area both when we pooled all species, and considered patch-forming and accompanying species separately (Table 3). However, this relationship was not hold when we segregated the data by dominant patch-forming species. The relationship between patch area and the density of accompanying species $\left(\mathrm{sp} / \mathrm{m}^{2}\right)$ could be fitted to a negative exponential function (LMM, density $=1.99 * \mathrm{e}^{-0.042 *}$ area, $\mathrm{p}<0.001$ ).

\subsection{Patch structure and composition}

Under woody patches, soils were shallow, ranging between 1.4 and $50.0 \mathrm{~cm}$ deep, and litter accumulation was highly variable showing a maximum under patches dominated by $Q$. coccifera. On average, woody 


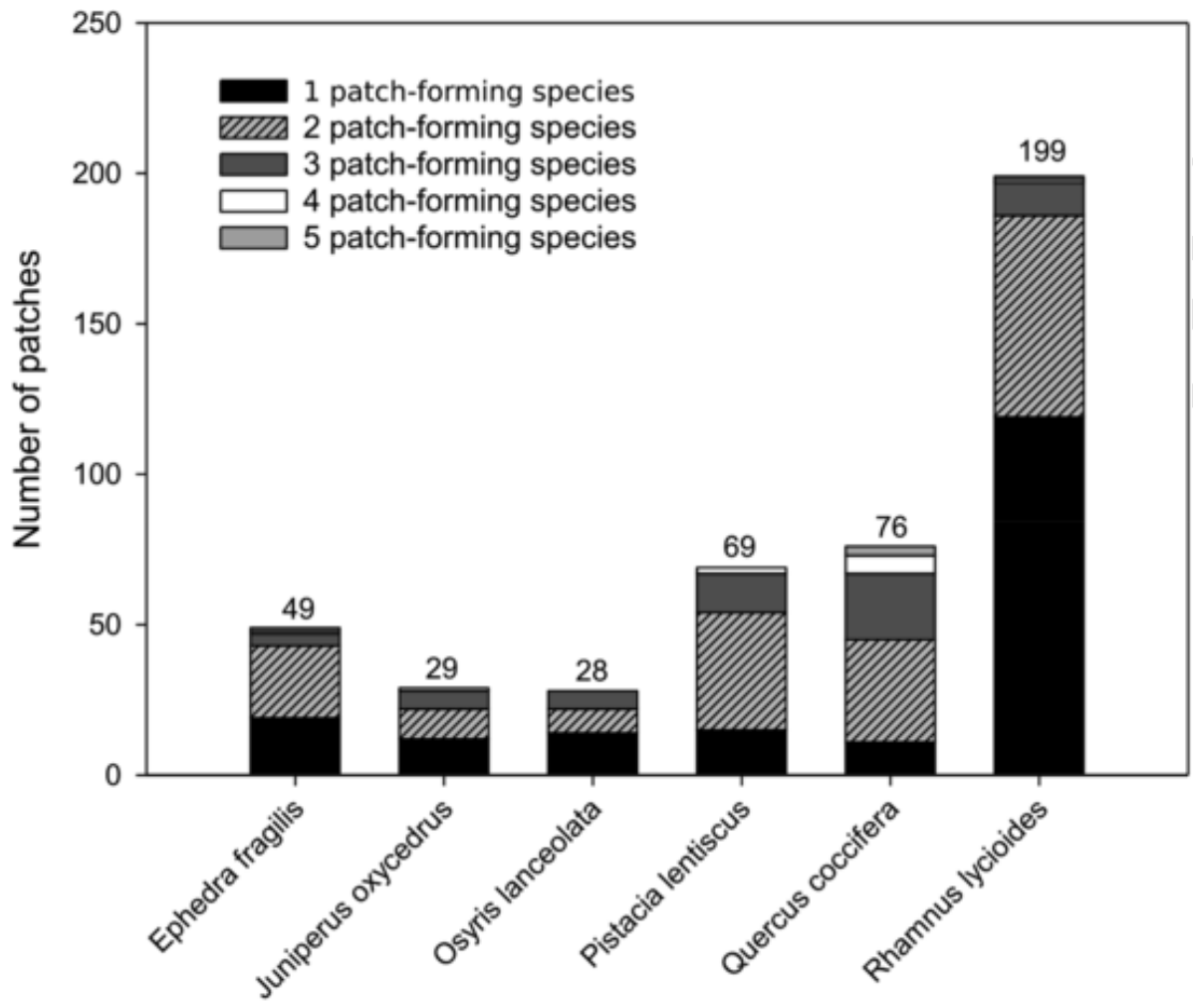

Patch-forming species

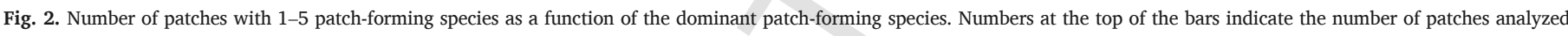
for each dominant patch-forming species.

Table 2

Main physical and biological attributes of the 450 woody patches selected in the studied catchments. Underneath and periphery refer to accompanying species located underneath patch-forming species and in their immediate periphery, respectively. Different letters indicate significant differences for richness and cover of accompanying species at $\mathrm{p}<0.05$

\begin{tabular}{lll}
\hline Patch attribute & Mean \pm SE & Range \\
\hline Patch height (m) & $1.61 \pm 0.02$ & $0.33-3.15$ \\
Patch area $\left(\mathrm{m}^{2}\right)$ & $11.2 \pm 0.6$ & $0.5-103.7$ \\
Litter depth (cm) & $1.3 \pm 0.1$ & $0.1-7.0$ \\
Soil depth (cm) & $20.0 \pm 0.5$ & $1.4-50.0$ \\
Number of patch-forming species & $2 \pm 1$ & $1-5$ \\
Number of accompanying species - underneath & $8 \pm 0 \mathrm{a}$ & $1-26$ \\
Number of accompanying species - periphery & $7 \pm 0 \mathrm{a}$ & $1-17$ \\
Total richness (Patch-forming + Accompanying- & $10 \pm 0$ & $2-29$ \\
underneath) & & \\
Cover accompanying species - underneath (\%) & $52.7 \pm 1.1 \mathrm{a}$ & $0.3-113.3$ \\
Cover accompanying species - periphery (\%) & $45.7 \pm 1.2 \mathrm{a}$ & $1.5-131.3$ \\
\hline
\end{tabular}

vegetation patches were $1.5 \mathrm{~m}$ high and covered $11 \mathrm{~m}^{2}$ (Table 2). Woody patches were formed by a combination of $1-5$ patch-forming species, and between 1 and 26 accompanying species. Yet, only in 16 out of the 450 patches coexisted more than 3 patch-forming species (Fig. 2 ). Average number of accompanying species in the patches ranged between 13.9 species per patch in patches dominated by $O$. lanceolata and 18.2 species per patch in patches dominated by Q. coccifera. Quercus coccifera patches hosted more species than patches dominated by any other patch-forming species. The biggest patches where those dominated by $Q$. coccifera, reaching a maximum projected area of $104 \mathrm{~m}^{2}$, followed by $P$. lentiscus patches (Table 4). Patches dominated by $R$. lycioides were the most abundant (199 patches out of 450; Fig.
Table 3

Estimated parameters of GLMM fits between patch area and the number of species in the patch (a: intercept, b: slope, p: p-value, $\mathrm{N}$ : number of patches in the analysis). P-values $<0.05$ are shown in bold. Spatial structure was taken into account by including catchment as a random factor in the analysis.

\begin{tabular}{|c|c|c|c|c|}
\hline Species considered in the analyses & a & $\mathrm{b}$ & $\mathrm{p}$ & $\mathrm{N}$ \\
\hline All species present in the patch & 17.26 & 0.084 & $<0.001$ & 450 \\
\hline Patch-forming species & 1.75 & 0.090 & $<0.001$ & 450 \\
\hline Accompanying species & 15.46 & 0.083 & $<0.001$ & 450 \\
\hline $\begin{array}{l}\text { Accompanying species in patches dominated } \\
\text { by Ephedra fragilis }\end{array}$ & 7.55 & 0.040 & 0.967 & 49 \\
\hline $\begin{array}{l}\text { Accompanying species in patches dominated } \\
\text { by Juniperus oxycedrus }\end{array}$ & 7.62 & 0.034 & 0.173 & 29 \\
\hline $\begin{array}{l}\text { Accompanying species in patches dominated } \\
\text { by Osyris lanceolata }\end{array}$ & 6.66 & 0.048 & 0.352 & 28 \\
\hline $\begin{array}{l}\text { Accompanying species in patches dominated } \\
\text { by Pistacia lentiscus }\end{array}$ & 7.422 & 0.043 & 0.670 & 69 \\
\hline $\begin{array}{l}\text { Accompanying species in patches dominated } \\
\text { by Quercus coccifera }\end{array}$ & 8.707 & 0.047 & 0.108 & 76 \\
\hline $\begin{array}{l}\text { Accompanying species in patches dominated } \\
\text { by Rhamnus lycioides }\end{array}$ & 7.858 & 0.042 & 0.378 & 199 \\
\hline
\end{tabular}

2). Patches dominated by $J$. oxycedrus and $O$. lanceolata were the least abundant.

We recorded 92 accompanying species. Some were widespread: Stipa tenacissima and B. retusum, were present in more than $50 \%$ of the sampled area, followed by Asparagus horridus, Fagonia cretica, Fumana ericoides, Globularia alypum and Helianthemum violaceum, that were present in more than one third of the sampled area.

The number of accompanying species underneath and at the periphery of the patches was not significantly different (Table 2). Yet, the 
Table 4

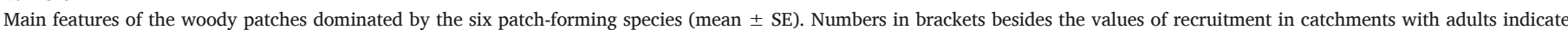

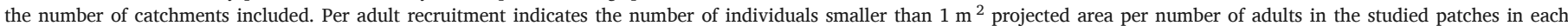

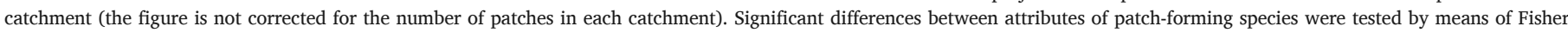

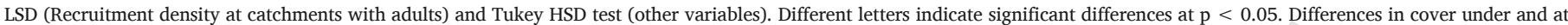
the periphery of the patches were tested by means of GLMM (n.s. indicates no significant differences, ** indicates $\mathrm{p}<0.01$ ).

\begin{tabular}{|c|c|c|c|c|c|c|c|c|c|c|}
\hline & \multirow[t]{2}{*}{$\begin{array}{l}\text { Patch area } \\
\left(\mathrm{m}^{2}\right)\end{array}$} & \multicolumn{3}{|c|}{ Cover accompanying species (\%) } & \multicolumn{3}{|c|}{ Number of accompanying species } & \multicolumn{2}{|c|}{$\begin{array}{l}\text { Recruitment density of patch- } \\
\text { forming species (juveniles/ha) }\end{array}$} & \multirow[t]{2}{*}{$\begin{array}{l}\text { Per adult } \\
\text { recruitment }\end{array}$} \\
\hline & & $\begin{array}{l}\text { Under } \\
\text { patches }\end{array}$ & $\begin{array}{l}\text { Around } \\
\text { patches }\end{array}$ & $\begin{array}{l}\text { Differences } \\
\text { GLMM }\end{array}$ & $\begin{array}{l}\text { Under } \\
\text { patches }\end{array}$ & $\begin{array}{l}\text { Around } \\
\text { patches }\end{array}$ & $\begin{array}{l}\text { Differences } \\
\text { GLMM }\end{array}$ & $\begin{array}{l}\text { All } \\
\text { catchments }\end{array}$ & $\begin{array}{l}\text { Catchments with } \\
\text { adults }\end{array}$ & \\
\hline $\begin{array}{l}\text { Quercus } \\
\text { coccifera }\end{array}$ & $27.1 \pm 2.5 a$ & $48.0 \pm 2.9$ & $39.1 \pm 2.7$ & n.s. & $10.4 \pm 0.5$ & $7.7 \pm 0.3$ & $* *$ & $3.9 \pm 2.4 b$ & $17.3 \pm 9.9 a(3)$ & $0.79 \pm 1.47 b$ \\
\hline $\begin{array}{l}\text { Pistacia } \\
\text { lentiscus }\end{array}$ & $13.8 \pm 1.1 b$ & $52.1 \pm 2.7$ & $48.8 \pm 3.0$ & n.s. & $8.5 \pm 0.5$ & $6.4 \pm 0.3$ & $* *$ & $17.5 \pm 6.8 b$ & $\begin{array}{l}52.9 \pm 19.5 a \\
(4)\end{array}$ & $1.18 \pm 1.64 b$ \\
\hline $\begin{array}{l}\text { Rhamnus } \\
\text { lycioides }\end{array}$ & $6.4 \pm 0.3 c$ & $54.0 \pm 1.7$ & $47.2 \pm 1.7$ & n.s. & $7.6 \pm 0.2$ & $7.9 \pm 0.2$ & n.s. & $124.4 \pm 3.0 \mathrm{a}$ & $\begin{array}{l}132.5 \pm 26.1 b \\
(14)\end{array}$ & $4.75 \pm 4.65 \mathrm{ab}$ \\
\hline $\begin{array}{l}\text { Juniperus } \\
\text { oxycedrus }\end{array}$ & $7.1 \pm 0.9 c$ & $43.6 \pm 6.8$ & $41.5 \pm 5.2$ & n.s. & $7.4 \pm 0.7$ & $7.6 \pm 0.5$ & $* *$ & $27.2 \pm 10.0 \mathrm{~b}$ & $\begin{array}{l}72.3 \pm 24.1 \mathrm{ab} \\
(5)\end{array}$ & $6.18 \pm 7.76 a$ \\
\hline $\begin{array}{l}\text { Ephedra } \\
\text { fragilis }\end{array}$ & $8.3 \pm 0.7 \mathrm{bc}$ & $54.5 \pm 2.9$ & $41.9 \pm 3.6$ & n.s. & $7.8 \pm 0.3$ & $7.5 \pm 0.3$ & n.s. & $38.2 \pm 11.6 b$ & $\begin{array}{l}72.4 \pm 20.5 a b \\
(7)\end{array}$ & $5.93 \pm 7.17 a$ \\
\hline $\begin{array}{l}\text { Osyris } \\
\text { lanceolata }\end{array}$ & $5.3 \pm 0.6 c$ & $65.5 \pm 4.1$ & $57.6 \pm 4.3$ & n.s. & $8.1 \pm 0.5$ & $5.8 \pm 0.5$ & $* *$ & $14.3 \pm 5.2 b$ & $\begin{array}{l}55.6 \pm 16.6 \mathrm{ab} \\
(3)\end{array}$ & $1.35 \pm 1.97 \mathrm{~b}$ \\
\hline
\end{tabular}

number of accompanying species was higher under patches dominated by $P$. lentiscus, $Q$. coccifera and $O$. lanceolata than in the periphery of those patches (Table 4). The cover of accompanying species in the periphery of the patches was lower than underneath them (LMM, $\mathrm{p}<0.05$, Table 2), but this difference was not present when we studied the patches of each species separately (LMM, p > 0.05, Table 4).

The composition of the community of accompanying species underneath and in the periphery of the patches differed (Table S2). Most species showed higher cover underneath the patches than in their periphery. In contrast, the cover of a few species was higher in the periphery. These included Fumana ericoides, F. tymifolia, Globularia alypum, Plantago albicans and $S$. tenacissima. Other species, largely the less abundant species, appeared exclusively under the patches (18\% of accompanying species) or at their periphery ( $3 \%$ of accompanying species). Finally, the abundance of species as Erica multiflora, Helianthemum spp., Cistus spp, Phagnalon spp., Rosmariuns officinalis, Sedum album, Sideritis leucantha, Stipa parviflora, Teucrium spp. and Thymus vulgaris was similar in both microhabitats.

The number of species under the patches and at their periphery was positively related to patch area both when we pooled all species together, and when we considered patch-forming and accompanying species separately (Table 3 ). The relationship between patch area and the density of accompanying species $\left(\mathrm{sp} / \mathrm{m}^{2}\right)$ could be fitted to a negative exponential function (LMM, density $=1.99 * \mathrm{e}^{-0.042 * \text { area }}$, $\mathrm{p}<0.001$ ). Conversely, the relationship between patch area and the number of accompanying species was not hold when we segregated the data by the dominant patch-forming species in each patch.

\subsection{Drivers of the abundance of patch-forming species}

The relationship between climate and the abundance of woody patches was highly dependent on the dominant species. Rhamnus lycioides patches were the most abundant under warmer conditions (Fig. 3). Conversely, Q. coccifera and J. oxycedrus patches were more abundant at lowest temperatures. Rhamnus lycioides patches were also abundant under the driest conditions, together with patches of $Q$. coccifera, $J$. oxycedrus and $E$. fragilis. In the wettest sites, $O$. lanceolata patches were more abundant than patches dominated by other species. Although all patch-forming species were present in most catchments, patches dominated by $O$. lanceolata, Q. coccifera and $J$. oxycedrus were more abundant at specific catchments, and thus, appeared to be associ-

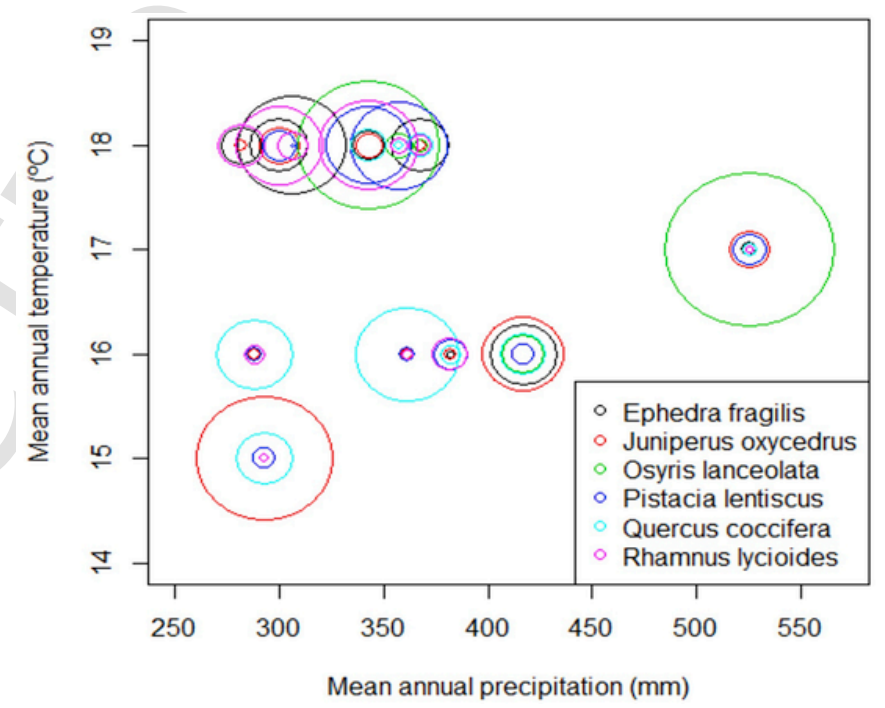

Fig. 3. Distribution of woody patches along gradients of mean annual air temperature and precipitation. Circle size corresponds to the relative abundance of patches dominated by a given patch-forming species with respect to the total number of patches dominated by this species in all catchments. For example, most patches dominated by Juniperus oxycedrus were located in the catchment with lower values of mean annual temperature and precipitation (Ventós 1).

ated to specific climatic conditions. Patches dominated by $O$. lanceolata were more abundant under warm conditions, but they were present under a wide range of precipitation levels. Patches dominated by J. oxycedrus were more abundant in colder sites and at a relative wide range of precipitations. Patches dominated by $Q$. coccifera showed the maximum abundance at low mean annual temperatures and low mean annual precipitation (288-361 mm).

All explanatory variables, but the cover of loose rocks, were related to the ordination axes (NMDS, stress $=0.04,4$ dimensions; Fig. 4 A). The relation was stronger for temperature $\left(R^{2}=0.310\right)$, precipitation $\left(R^{2}=0.158\right)$ and plant cover $\left(R^{2}=0.088\right)$. For the remaining variables, the relation was weaker $\left(R^{2}<0.04\right.$, Table S3). Hence, the composition of patch-forming species in the patches was mainly determined by temperature (related to axis 1) and precipitation (related to axis 2). The highest correlations between species cover and the ordination axes 


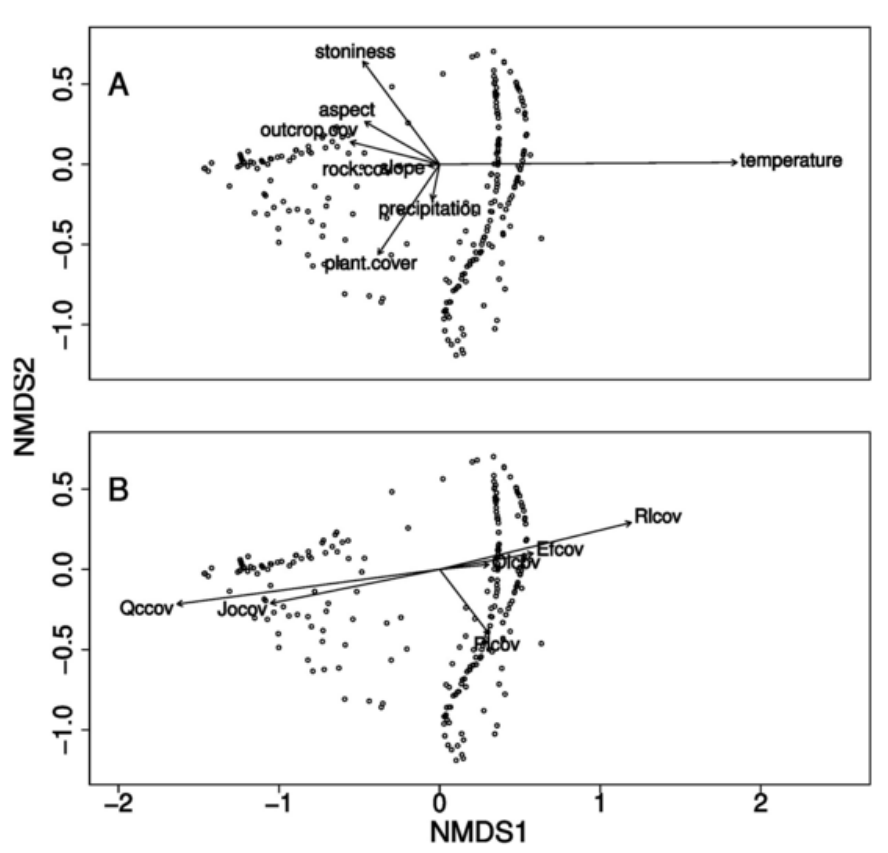

Fig. 4. NMDS ordination of the patches based on the cover of patch-forming species showing their relationship with environmental variables (A) and the cover of patch-forming species (B) (results of the statistical analyses in Tables S3 and S4). Arrow length and direction corresponds to the magnitude and sign of the correlation coefficients between each variable and the ordination axes. Efcov: cover of Ephedra fragilis, Jocov: cover of Juniperus oxycedrus, Olcov: cover of Osyris lanceolata, Plcov: cover Pistacia lentiscus, Qccov: cover of Quercus coccifera, Rlcov: cover of Rhamnus lycioides.

corresponded to $R$. lycioides $\left(\mathrm{R}^{2}=0.862\right), Q$. coccifera $\left(\mathrm{R}^{2}=0.653\right)$ and $P$. lentiscus $\left(\mathrm{R}^{2}=0.437\right)$. Correlation coefficients for other species were below 0.2 (Fig. 4 B, Table S4). Considering the relation between ordination axes and environmental variables, the abundances of $Q$. coccifera and $R$. lycioides were related to low and high temperatures, respectively, whereas conditions of lower stoniness and higher precipitation and plant cover favored the abundance of $P$. lentiscus.

\subsection{Drivers of the abundance of accompanying species}

Temperature was the main variable influencing the ordination of accompanying species (NMDS, stress $=0.18,4$ dimensions; $\mathrm{R}^{2}=0.317$ ), and was strongly related to the first NMDS axis (Fig. 5 A; Table S5). Aspect and the cover of rock outcrops were related to the first axis, while stoniness and plant cover were related to the second axis. Other variables, namely slope, precipitation and rock cover, were not related to the composition of accompanying species.

The fit of the cover of patch-forming species on the ordination axes for accompanying species was lower than for environmental variables. Most patch-forming species (with the exception of $O$. lanceolata) were significantly but weakly correlated to the cover of accompanying species community $\left(\mathrm{R}^{2}=0.138\right.$ and $\mathrm{R}^{2}=0.077$ for $Q$. coccifera and $R$. lycioides, respectively; Fig. $5 \mathrm{~B}$, Table S6). Most species related to the first axis of the ordination either negatively $(Q$. coccifera and $J$. oxycedrus) or positively (E. fragilis and R. lycioides), while P. lentiscus was related to both axes.

Fifty-eight accompanying species showed a significant correlation with at least one of the two first ordination axes (Fig. 5 C). Yet, only six of them showed a correlation coefficient higher than 0.5. Carex humilis, Polygala rupestris and Teucrium pseudochamaepytis correlated negatively to axis 1 and thus with temperature, whereas Fagonia cretica correlated positively with the same axis. Two species showed strong correlations with axis $2\left(\mathrm{R}^{2}>0.5\right)$, either negative (Brachypodium retusum) or positive (S. tenacissima), suggesting that $B$. retusum increased as plant
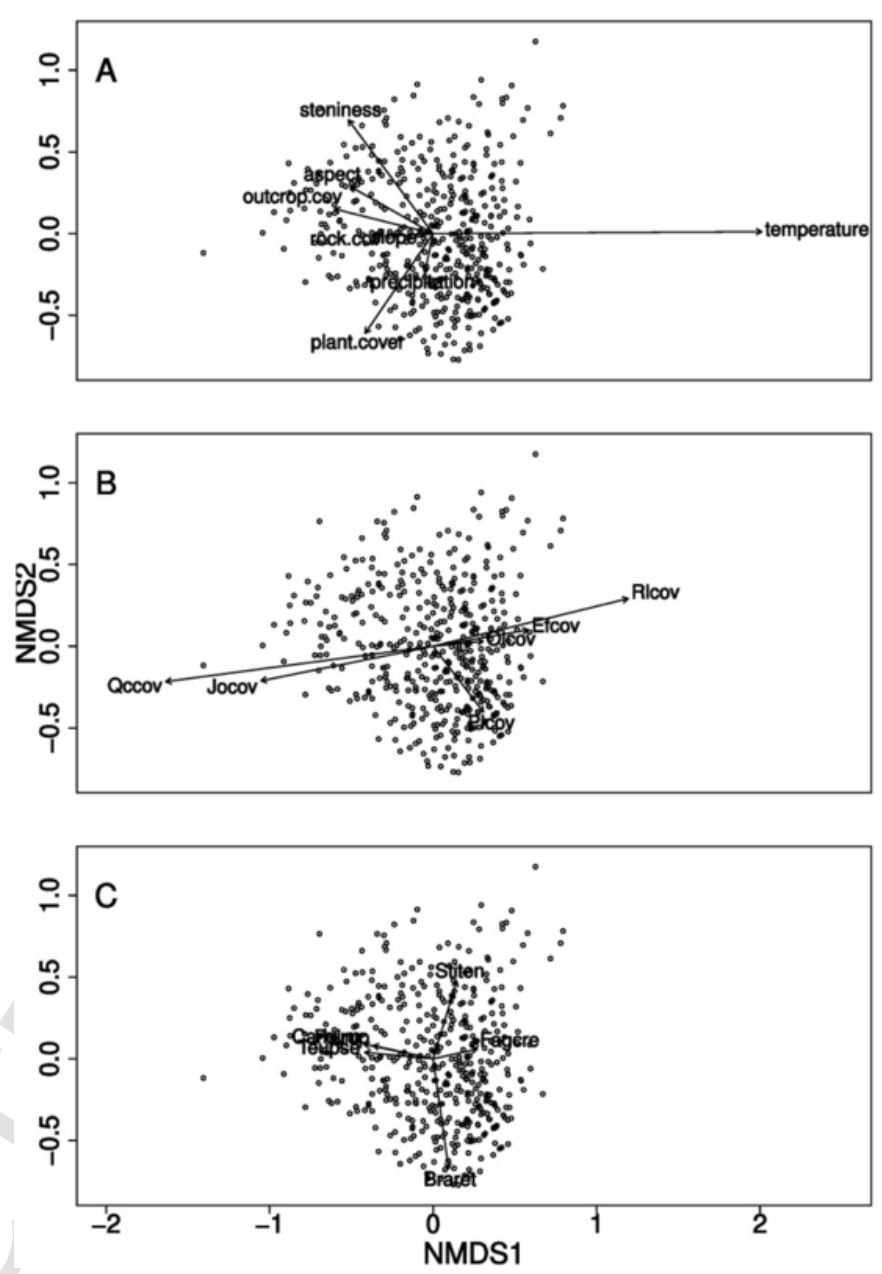

Fig. 5. NMDS ordination of the patches based on the cover of accompanying species showing their relationship with environmental variables (A), cover of patch-forming species (B) and the cover of accompanying species (C) (results of the statistical analyses in Tables S5 and S6). Only highly correlated species $\left(\mathrm{R}^{2}>0.5\right)$ in plot $\mathrm{C}$ are shown for clarity. Arrow length and direction corresponds to the magnitude and sign of the correlation coefficients between each variable and the ordination axes. Patch-forming species: Efcov (Ephedra fragilis), Jocov (Juniperus oxycedrus), Olcov (Osyris lanceolata), Plcov (Pistacia lentiscus), Qccov (Quercus coccifera), Rlcov (Rhamnus lycioides). Accompanying species: Braret (Brachypodium retussum), Carhum (Carex humilis), Fagcre (Fagonia cretica), Polrup (Polygala rupestris), Stiten (Stipa tenacissima) and Teupse (Teucrium pseudochamaepytis).

cover increased and stoniness decreased, and S. tenacissima followed the opposite trend.

To assess the relative influence of environmental variables and patch-forming species on the cover of accompanying species described by the NMDS, we run a PERMANOVA analysis (Table 5). The effects of all variables were significant. However, they explained a relatively low proportion of the model variance. Only three variables explained more than $5 \%$ of the variation each: temperature $(9.4 \%)$, plant cover $(8.2 \%)$ and the cover of rock outcrops (5.5\%). Four explanatory variables showed a significant interaction with catchment: stoniness, aspect, temperature and cover of $E$. fragilis. Stoniness explained $52 \%$ of the model variance, indicating that the effect of stoniness on species composition was strongly dependent on catchment properties. Each of the other interactions explained less than $5 \%$ of the variance of the model.

\subsection{Recruitment of patch-forming species}

The density of juveniles of patch-forming species ranged from 11 to 508 individuals $\cdot \mathrm{ha}^{-1}$. Density depended on the species considered: 
Table 5

Factors controlling the composition of the accompanying species community (percentage of variance of the PERMANOVA model explained by each factor). Asterisks indicate $\mathrm{p}$-value $\left(* * * \mathrm{p}<0.001,{ }^{*} \mathrm{p}<0.05\right)$

\begin{tabular}{lll}
\hline & Variable & Interaction with catchment \\
\hline Stoniness & $0.6 \% * * *$ & $51.5 \% * * *$ \\
Aspect & $0.6 \% * * *$ & $2.8 \% * * *$ \\
Temperature & $9.4 \% * * *$ & $4.8 \% * * *$ \\
Plant cover & $8.3 \% * * *$ & $0.6 \%$ \\
Rock outcrop cover & $5.5 \% * * *$ & $0.4 \%$ \\
Quercus coccifera cover & $0.2 \% *$ & $0.1 \%$ \\
Pistacia lentiscus cover & $0.4 \% * * *$ & $0.3 \%$ \\
Rhamnus lycioides cover & $1.0 \% * * *$ & $0.4 \%$ \\
Juniperus oxycedrus cover & $0.4 \% * * *$ & $0.3 \%$ \\
Ephedra fragilis cover & $1.1 \% * * *$ & $0.9 \% * * *$ \\
\hline
\end{tabular}

Rhamnus lycioides showed the largest recruitment, with an average of 124 juvenilesha ${ }^{-1}$ (GLMM and post-hoc Tukey-HSD test, $\mathrm{p}<0.05$; Table 4). The pattern was similar when we considered only catchments where adults of the patch-forming species were present. Species differed in the density of juveniles (GLMM, $\mathrm{p}<0.05$ ), but Tukey-HSD test showed no significant pairwise differences. Yet, Fisher-LSD test separated the species with highest density of juveniles ( $R$. lycioides) from the lowest (Q. coccifera and P. lentiscus), other species showing intermediate values. The density of juveniles was significantly related to precipitation (GLMM $\mathrm{p}=0.007)$, but not to temperature (GLMM $\mathrm{p}=0.143$ ).

Per adult recruitment (the number of juveniles of each species per adult of that species present in the studied patches in each catchment) differed among the different species. Juniperus oxycedrus and E. fragilis showed higher per adult recruitment, and $O$. lanceoloata, $P$. lentiscus and Q. coccifera showed the lowest values (GLMM and post-hoc Tukey-HSD test, $\mathrm{p}<0.05$ ). The number of juveniles of patch-forming species in a catchment did not correlate with the cover of patch-forming species in that catchment (GLMM, p = 0.503). We only found 4 juveniles of patch-forming species, whose adults were not present in their respective catchments.

\section{Discussion}

\subsection{Drivers of patch-forming species dominance and recruitment}

Climate determined the number of patches dominated by different patch-forming species in $S$. tenacissima steppes, and their relative cover. Patches dominated by $Q$. coccifera and J. oxycedrus showed their maximum abundance at low mean annual temperatures and low mean annual precipitations. Relative cover of patch-forming species within the patches showed a similar trend: as temperature increased, cover of $Q$. coccifera and $J$. oxycedrus decreased. This result was unexpected as $Q$. coccifera forms dense shrublands in Mediterranean sub-humid and humid areas (> $400 \mathrm{~mm}$ mean annual precipitation). Patches dominated by $R$. lycioides and $O$. lanceolata were more abundant under warmer and drier catchments, but the relative cover of these species within the patches was mainly determined by temperature, not precipitation.

Average temperatures in southeastern Spain are expected to increase by $2.5-3.5{ }^{\circ} \mathrm{C}$ in the next 75 years (IPCC et al., 2014). Most predictions point towards a decrease in average precipitation in this area, although the degree of certainty is much lower (Machado et al., 2011). Considering that the model of species dominance along gradients of mean annual temperature and precipitation described holds true under new climate scenarios, patches of $Q$. coccifera and $J$. oxycedrus will decline, whereas patches dominated by $R$. lycioides and $E$. fragilis will become more abundant over the next decades. Species shift in patch-forming species might have significant implications for the functioning of $S$. tenacissima steppes, because patch-forming species determine recruitment density, understory composition and ecosystem functioning (Maestre, 2004; Amat et al., 2015).

Recruitment of different patch-forming species differed. We must be careful at interpreting these patterns as indicators of population vitality or stagnation, as pulse recruitment is common in drylands (Chesson et al. (2004). We expected that, as climate (mainly temperature) determines the cover of dominant species, recruitment of those species would also be determined by climate. However, only mean annual precipitation but not mean annual temperature influenced recruitment. This difference could be due to the fact that recruitment is about number of individuals but cover is about a combination of number and size of individuals. Hence cover will depend on number of patches but also on the area of the patches. Patch size may or may not be determined by the same factors as patch density. For example, in our study $Q$. coccifera generated comparatively big patches but low recruitment. Similarly, $P$. lentiscus germination is linked to the coincidence of persistent rain events and high temperatures (García-Fayos and Verdú, 1998), a combination that may not affect adult growth in the same way.

We hypothesized that abandoned terraces, and particularly stone walls, acted as local refugia for patch-forming species. Therefore, as S. tenacissima crops in slopes were abandoned (mostly during the second half of the 20th century; Fernández-Palazón, 1974; Rolo et al., 2016), species present in the terraces would expand along the slopes. However, the cover of patch-forming species in abandoned crop terraces did not correlate with the number of woody patches in the slopes or the number of seedlings of patch-forming species in the slopes. On the one hand, expansion trajectories from abandoned terraces may be blurred by the presence of old isolated individuals in slopes, and particularly in ridges which could protect these species during the peak of fiber harvesting activities. The observed pattern may also be explained by the dispersal strategy of these species. Most patch-forming species are zoochorous, and long-distance transport from inside and outside the catchments is likely. Yet, we must take into account that juveniles of particular patch-forming species were barely present in catchments where these species were absent. Finally, the scale of our study may not be adequate to reveal these patterns. Further analysis of the spatial distribution of the patches and patch-forming species could shed new insights on the role of abandoned terraces as sources of propagules.

\subsection{Drivers of accompanying species}

The number of accompanying species increased with patch size. This supports the view of patches act as islands (Maestre and Cortina, 2005). Yet, we also found that species density decreases as patch area increases: small patches are relatively richer in accompanying species than bigger ones. This pattern may be explained by various processes, including competitive interactions between accompanying species (Maestre et al., 2004; Verdú et al., 2009).

This may be because an increased patch area does not result in an increased number or an increased area of habitats inside the patches but in an increase of the most inner part, which may be relatively homogeneous and not particularly favorable in terms of water and light availability (Reisman-Berman, 2007; Holmgren et al., 2010).

The cover of accompanying species was mainly determined by temperature, as indicated by NMDS and PERMANOVA analyses. It was not possible to incorporate catchment as a random factor in the PERMANOVA. Instead, we assessed the effect of catchment by including the interaction between this factor and explanatory variables. The interaction between stoniness and catchment explained a high proportion of the variability in the composition of accompanying species, emphasizing the importance of stoniness as a driver of the composition of the accompanying species in each catchment. 
Patches generated different microhabitats, as evidenced by differences in the composition of accompanying species under and around them. In most cases, the number and cover of accompanying species was higher under the patches than at the periphery, suggesting that the positive effect exerted by the patches could offset competition for light and water. It also shows that patch effects decrease rapidly beyond their projected area, as noted by Amat et al. (2015). The ability to modify the composition of accompanying species depended on the dominant patch-forming species, which is in agreement with studies in drylands elsewhere (Blank and Carmel, 2012; Zhang et al., 2016).

Most accompanying species where more abundant under the patches than at the periphery. The few species restricted to the periphery ( $F$. ericoides, F. thymifolia, G. alypum, P. albicans and S. tenacissima) are associated with open habitats. Most species appearing exclusively underneath the patches (e.g., $C$. humilis, $P$. rupestris and $R$. peregrina) were shade-tolerant mesic species that may find suitable microhabitat underneath them, and whose presence in these steppes may be linked to the fate of woody patches. In this respect, Verdú et al. (2009) showed the important role that philogenetic distance may play in filtering species in patch understory.

Finally, species whose frequency was similar at both microhabitats are generalists in this Mediterranean sector of the Iberian Peninsula, and they are well fitted to the range of temperature and precipitation encompassed in this study. It is worth noting that the density of some species was very low. For some of them, as P. angustifolia and C. humilis, $S$. tenacissima steppes represent their southernmost distribution. However, for others (e.g., O. europaea and S. genistoides) the scarcity was unexpected, as they are within their core distribution area, and they commonly show good performance when planted (Valdecantos et al., 2014). This contrasting result, could be due to the fact that in most restoration programs plants are introduced as seedlings, hence they have already overcome the germination and establishment phases, and the environmental or biotic constraints affecting germination and establishment may not be so stressful for the establishment of seedlings (Gómez-Aparicio and Peters, 2008), but we cannot exclude the possibility that previous land use had a negative effect on the abundance of these species.

\subsection{Concluding remarks}

Woody patches in S. tenacissima steppes are dominated by a few patch-forming species, but complex communities organize around them. Different patch-forming species modify the environment differently, promoting dissimilarities in accompanying species assemblages. Temperature is the main determinant of the abundance of patch-forming species, but all species are not equally sensitive to it. Recruitment also depends on the identity of the patch-forming species. While some species (particularly R. lycioides) are particularly abundant and successful recruiters, other (mainly $Q$. coccifera) show a much more conservative strategy, suggesting that they may be unable to cope with future climate scenarios. Hence, patch persistence and expansion may be guaranteed when $R$. lycioides is present, and this species may increase its presence under warmer and drier conditions. Conversely, $Q$. coccifera patches were the biggest and accommodated the highest number of species: a reduction of the number of patches of this species could have a cascading effect on biodiversity of $S$. tenacissima steppes. Our study shows that woody patches in $S$. tenacissima steppes are highly diverse in structure and composition, and generalities on the response of patches and steppes to climate change should be made with care.

\section{Declaration of competing interest}

The authors declare that they have no known competing financial interests or personal relationships that could have appeared to influence the work reported in this paper.

\section{Acknowledgements}

This research has been financially supported by the Spanish Ministry of Science, Education and Universities and European Regional Development Funds (FEDER), (projects UNCROACH, CGL2011-30581-C02-01 and COSTERA, RTI2018-095954-B-I00). JT was supported by a Juan de la Cierva Contract and BA was supported by an FPU fellowship, both from the Spanish Ministry of Science and Innovation. We also thank María Joao Ribeiro Da Silva, Lucía de Soto, Lorena Guixot, Núria Jover, Adela Blasco, Alejandro Pastor and Elisa Cantán for their collaboration in the field surveys.

\section{Appendix A. Supplementary data}

Supplementary data to this article can be found online at https://doi. org/10.1016/j.jaridenv.2020.104246.

\section{References}

Aguiar, M R, Sala, O E, 1999. Patch structure, dynamics and implications for the functioning of arid ecosystems. Trends Ecol. Evol. 14, 273-277.

Aguiar, M R, Soriano, A, Sala, O E, 1992. Competition and facilitation in the recruitment of seedlings in patagonian steppe. Funct. Ecol. 6, 66. doi:10.2307/2389772.

Amat, B, Cortina-Segarra, J, Zubcoff, J J, 2015. Community attributes determine facilitation potential in a semi-arid steppe. Perspect. Plant Ecol. Evol. Systemat. 17, 24-33. doi:10.1016/j.ppees.2014.10.001.

Archer, N A L, Quinton, J N, Hess, T M, 2002. Below-ground relationships of soil texture, roots and hydraulic conductivity in two-phase mosaic vegetation in South-east Spain. J. Arid Environ. 52, 535-553. doi:10.1006/jare.2002.1011.

Arroyo, A I, Pueyo, Y, Saiz, H, Alados, C L, 2015. Plant-plant interactions as a mechanism structuring plant diversity in a Mediterranean semi-arid ecosystem. Ecol. Evol. 5, 5305-5317. doi:10.1002/ece3.1770.

Bates, D, Maechler, M, Bolker, B, Walker, S, 2015. Fitting linear mixed-effects models using lme4. J. Stat. Software 67 (1), 1-48. doi:10.18637/jss.v067.i01.

Berdugo, M, Delgado-Baquerizo, M, Soliveres, S, Hernández-Clemente, R, Zhao, Y, Gaitán, J J, Gross, N, Saiz, H, Maire, V, Lehman, A, Rillig, M C, Solé, R V, Maestre, F T, 2020. Global ecosystem thresholds driven by aridity. Science 367 (6479), 787-790. doi:10.1126/science.aay5958.

Blank, L, Carmel, Y, 2012. Woody vegetation patch types affect herbaceous species richness and composition in a Mediterranean ecosystem. Community Ecol. 13, 72-81.

Castillo-Escrivà, A, López-Iborra, G M, Cortina-segarra, J, Tormo, J, 2019. The use of branch piles to assist in the restoration of degraded semiarid steppes. Restor. Ecol. 27, 102-108. doi:10.1111/rec.12704.

Chesson, P, Gebauer, R L E, Schwinning, S, Huntly, N, Wiegand, K, Ernest, M S K, Sher, A, Novoplansky, A, Weltzin, J F, 2004. Resource pulses, species interactions, and diversity maintenance in arid and semi-arid environments. Oecologia 141, 236-253.

Cortina, J, Maestre, F T, Ramírez, D, 2009. Innovations in Semiarid Land Restoration. The Case of Stipa Tenacissima L. Steppes. Land Restoration to Combat Desertification. Innovative Approaches, Quality Control and Project Evaluation. Fundación CEAM, Valencia, pp. 121-144.

Doblas-Miranda, E, Sánchez-Piñero, F, González-Megías, A, 2009. Different microhabitats affect soil macroinvertebrate assemblages in a Mediterranean arid ecosystem. Appl. Soil Ecol. 41, 329-335.

del Esparto, Servicio, 1953. Estudios Y Experiencias Sobre El Esparto, Vol II. Ministerios de Industria y Comercio y de Agricultura, Madrid, Spain.

Fernández-Palazón, G, 1974. Aspectos socioeconómicos de la explotación del esparto en España. Rev. Geogr. VIII, 203-2012.

García-Fayos, P, Verdú, M, 1998. Soil seed bank, factors controlling germination and establishment of a Mediterranean shrub: Pistacia lentiscus L. Acta Oecol. 19, 357-366.

Gasque, M, García-Fayos, P, 2004. Interaction between Stipa tenacissima and Pinus halepensis: consequences for reforestation and the dynamics of grass steppes in semi-arid Mediterranean areas. For. Ecol. Manag. 189 (1-3), 251-261.

Gómez-Aparicio, L, 2008. Spatial patterns of recruitment in Mediterranean plant species: linking the fate of seeds, seedlings and saplings in heterogeneous landscapes at different scales. J. Ecol. 96, 1128-1140. doi:10.1111/j.1365-2745.2008.01431.

Hochstrasser, T, Peters, D P C, 2004. Subdominant species distribution in microsites around two life forms at a desert grassland-shrubland transition zone. J. Veg. Sci. 15, $615-622$. 
Holmgren, M, Scheffer, M, Huston, M A, 2010. The interplay of facilitation and competition in plant communities. Ecology 78, 1966-1975.

Huang, J, Yu, H, Guan, X, Wang, G, Guo, R, 2016. Accelerated dryland expansion under climate change. Nat. Clim. Change 6, 166-171. doi:10.1038/nclimate2837.

Hurlbert, S H, 1997. Functional importance vs keystoneness: reformulating some questions in theoretical biocenology. Austral Ecol. 22, 369-382.

IPCC, 2014. In: Pachauri, R K, Meyer, L A (Eds.), Climate Change 2014: Synthesis Report. Contribution of Working Groups I, II and III to the Fifth Assessment Report of the Intergovernmental Panel on Climate Change. IPCC, Geneva, Switzerland.

Ludwig, J A, Tongway, D J, 1995. Spatial organisation of landscapes and its function in semi-arid woodlands, Australia. Landsc. Ecol. 10, 51-63.

Ludwig, J A, Tongway, D J, Bastin, G N, James, C D, 2004. Monitoring ecological indicators of rangeland functional integrity and their relation to biodiversity at local to regional scales. Austral Ecol. 29, 108-120. doi:10.1111/j.1442-9993.2004.01349.x.

Machado, M J, Benito, G, Barriendos, M, Rodrigo, F S, 2011. 500 Years of rainfall variability and extreme hydrological events in southeastern Spain drylands. J. Arid Environ. 75, 1244-1253.

Maestre, F T, 2004. On the importance of patch attributes, environmental factors and past human impacts as determinants of perennial plant species richness and diversity in Mediterranean semiarid steppes. Divers. Distrib. 10, 21-29.

Maestre, F T, Cortina, J, 2004. Do positive interactions increase with abiotic stress? A test from a semi-arid steppe. Proc. R. Soc. Lond. Ser. B Biol. Sci. 271 (Suppl. 1_5), S331-S333.

Maestre, F T, Cortina, J, 2005. Remnant shrubs in Mediterranean semi-arid steppes: effects of shrub size, abiotic factors and species identity on understorey richness and occurrence. Acta Oecologica Int. J. Ecol. 27, 161-169.

Maestre, F T, Cortina, J, Bautista, S, 2004. Mechanisms underlying the interaction between Pinus halepensis and the native late-successional shrub Pistacia lentiscus in a semi-arid plantation. Ecography 27 (6), 776-786.

McCune, B, Grace, J B, 2002. Analysis of Ecological Communities. MjM Software Design, Glenden Beach. Oregon, USA.

Merino-Martín, L, Moreno-de las Heras, M, Espigares, T, Nicolau, J M, 2015. Overland flow directs soil moisture and ecosystem processes at patch scale in Mediterranean restored hillslopes. Catena 133, 71-84. doi:10.1016/j.catena.2015.05.002.
Ninyerola, M, Pons, X, Roure, J M, 2005. Atlas Climático Digital De La Península Ibérica. Universtat Autonoma de Barcelona, p. 45.

J. Oksanen F. Blanchet G. M. Friendly R. Kindt P. Legendre D. McGlinn P.R. Minchin R.B. O'Hara G.L. Simpson P. Solymos M. Henry H. Stevens E. Szoecs H. Wagner Vegan: community ecology packageR package version 2.5-6https://CRAN.R-project.org/ package $=$ vegan 2019

Pescador, D S, Chacón-Labella, J, de la Cruz, M, Escudero, A, 2014. Maintaining distances with the engineer: patterns of coexistence in plant communities beyond the patch-bare dichotomy. New Phytol. 204, 140-148. doi:10.1111/nph.12899.

Prăvălie, R, 2016. Drylands extent and environmental issues. A global approach. Earth Sci. Rev. 161, 259-278. doi:10.1016/j.earscirev.2016.08.003.

R Development core team, 2018. R: A Language and Environment for Statistical Computing.

Reisman-Berman, O, 2007. Age-related change in canopy traits shifts conspecific facilitation to interference in a semi-arid shrubland. Ecography 30, 459-470.

Rolo, V, Amat, B, Cortina, J, 2016. Water availability and species identity control shrub colonization in abandoned semiarid steppes. Agric. Ecosyst. Environ. 228, 62-69. doi:10.1016/j.agee.2016.05.014.

Soliveres, S, Eldridge, D J, Müller, J D, Hemmings, F, Throop, H L, 2015. On the interaction between tree canopy position and environmental effects on soil attributes and plant communities. J. Veg. Sci. 26, 1030-1042. doi:10.1111/jvs.12312.

Tormo, J, Cortina-segarra, J, García-Barreda, S, 2012. Selección de especies para restauración mediante modelos de germinación hidrotermal. In: Martinez-Ruiz, C, Lario Leza, F J, Fernandez Santos, B (Eds.), Avances En La Restauración de Sistemas Forestales. Tácnicas de Implantación. Asociación Española de Ecología Terrestre (AEET) y Sociedad Española de Ciencias Forestales (SECF). pp. 203-208 Palencia.

Valdecantos, A, Fuentes, D, Smanis, A, Llovet, J, Morcillo, L, Bautista, S, 2014. Effectiveness of low-cost planting techniques for improving water availability to olea europaea seedlings in degraded drylands. Restor. Ecol. 22, 327-335.

Verdú, M, Rey, P J, Alcántara, J M, Siles, G, Valiente-Banuet, A, 2009. Phylogenetic signatures of facilitation and competition in successional communities. J. Ecol. 97, 1171-1180. doi:10.1111/j.1365-2745.2009.01565.x.

Zhang, G, Zhao, L, Yang, Q, Zhao, W, Wang, X, 2016. Effect of desert shrubs on fine-scale spatial patterns of understory vegetation in a dry-land. Plant Ecol. 217, 1141-1155. doi:10.1007/s11258-016-0639-0. 